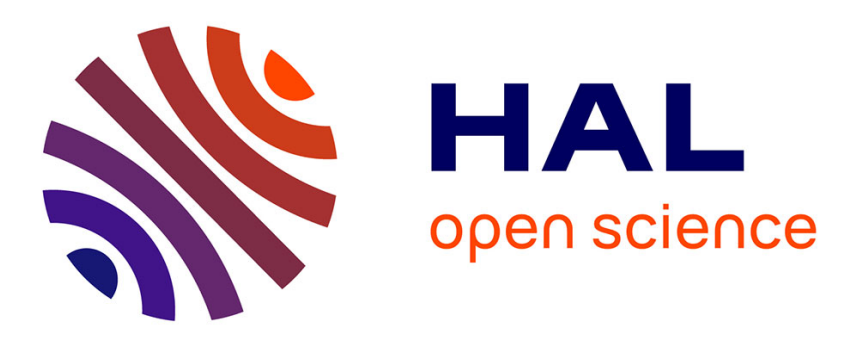

\title{
Experimental assessment of an active (acoustic) liner prototype in an acoustic flow duct facility
}

Kevin Billon, E de Bono, M Perez, E Salze, G Matten, M Gillet, M Ouisse, M Volery, H Lissek, J Mardjono, et al.

\section{- To cite this version:}

Kevin Billon, E de Bono, M Perez, E Salze, G Matten, et al.. Experimental assessment of an active (acoustic) liner prototype in an acoustic flow duct facility. SPIE, Mar 2021, Los Angeles, United States. 10.1117/12.2583099 . hal-03236906

\section{HAL Id: hal-03236906 https://hal.science/hal-03236906}

Submitted on 26 May 2021

HAL is a multi-disciplinary open access archive for the deposit and dissemination of scientific research documents, whether they are published or not. The documents may come from teaching and research institutions in France or abroad, or from public or private research centers.
L'archive ouverte pluridisciplinaire HAL, est destinée au dépôt et à la diffusion de documents scientifiques de niveau recherche, publiés ou non, émanant des établissements d'enseignement et de recherche français ou étrangers, des laboratoires publics ou privés. 


\title{
Experimental assessment of an active (acoustic) liner prototype in an acoustic flow duct facility
}

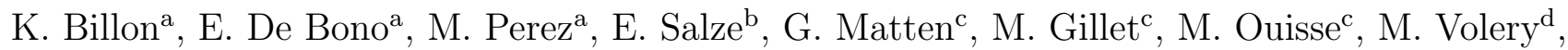 \\ H. Lissek ${ }^{\mathrm{d}}$, J. Mardjono ${ }^{\mathrm{e}}$, and M. Collet ${ }^{\mathrm{a}}$ \\ ${ }^{a}$ Univ. Lyon, École Centrale de Lyon, LTDS UMR 5513, F-69134 Ecully, France \\ ${ }^{b}$ Univ. Lyon, École Centrale de Lyon, LMFA UMR 5509, F-69134 Ecully, France \\ 'Univ. Bourgogne Franche-Comté, FEMTO-ST Institute, CNRS/UFC/ENSMM/UTBM, \\ Department of Applied Mechanics, 24 rue de l'Epitaphe, F-25000 Besançon, France \\ dSignal Processing Laboratory LTS2, Ecole Polytechnique Fédérale de Lausanne, Station 11, \\ CH-1015 Lausanne, Switzerland

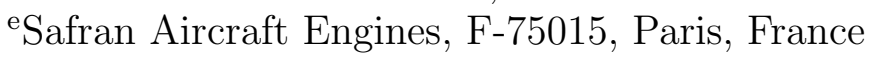

\begin{abstract}
In this paper, experimental results of broadband noise reduction in an acoustic flow duct are presented. An active liner composed of an array of electroacoustic absorbers is used. The control law is based on the pressure-based, current driven digital architecture for impedance control with a local control strategy. A wind tunnel test rig named Caïman has been used for the experimental validation. The results confirm the adaptability and the stability of the whole system with the local control strategy. The air flow slightly reduces the efficiency while maintaining the adaptability and the stability.
\end{abstract}

Keywords: Active liner, Electroacoustic absorber, Impedance control, Broadband noise reduction

\section{INTRODUCTION}

SALUTE (Smart Acoustic Lining for Ultra High By Pass Ratio (UHBR) Technologies Engines) is a research project funded by the European Union's Horizon 2020 research and innovation programme Clean Sky 2 Joint Undertaking. It aims to develop innovative acoustic treatments for engine nacelles in order to reduce noise pollution of future aircrafts. The main technological objective is to perfect a new generation acoustic liner, based on the Electroacoustic Absorber concept. UHBR Technologies Engines have larger fan and shorter nacelles which present new challenges in terms of noise signature (more low-frequency components and less space for acoustic liners). In order to meet the required noise performance at engine level, the next generation of acoustic treatments should achieve significant noise reduction with limited surface, in order to break the quarter-wavelength rule. It is in this context that this study takes place.

Active Liners can outperform conventional acoustic treatments (Single Degree of Freedom (SDOF) liner for example) and adapt their performances in real-time to varying engine speeds with an external source of energy. The active Noise Control (ANC) strategy proposed here is based on an electro-mechano-acoustical system. The pioneers works on the topic ${ }^{1}$ introduced an "electronic sound absorbers" with a loudspeaker and a nearby microphone in a negative feedback loop. A few decades later, an "active equivalent of a quarter wavelength resonator" was achieved through a hybrid passive-active technique. ${ }^{2}$ This strategy was retrieved by ${ }^{3}$ for liners applications.

Recently, the concept of electroacoustic absorber evolved with shunting techniques, ${ }^{4,5}$ direct feedback, ${ }^{6,7}$ or a sensorless control of the loudspeaker impedance. ${ }^{8}$ This pressure-based current-drive control architecture has

Further author information: (Send correspondence to Kevin Billon)

E-mail: kevin.billon@ec-lyon.fr 
been applied to design an active lining concept built an arrangement of electroacoustic absorbers. This concept allowed to achieve broadband noise reduction for aircraft engine nacelles applications under grazing flow. ${ }^{9}$

This paper presents a preliminary acoustic characterisation of a $2 \mathrm{D}$ active liner based on an array of electroacoustic absorbers. The control law is based on the pressure-based, current driven digital architecture for impedance control designed by Rivet et al. ${ }^{10} \mathrm{~A}$ local control strategy is experimentally validated without and with flow. This paper is organised as follow: section 2 describe the local control strategy, section 3 introduce the test bench facility and the experimental results are finally presented in section 4 .

\section{LOCAL CONTROL STRATEGY}

The active liner is based on an arrays of unit cells. Each unit cell is composed of a transducer (a loudspeaker), 4 microphones and a control card with localized control strategy (Figure 1).

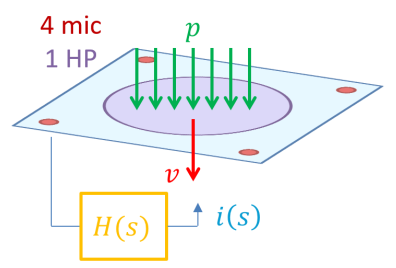

Figure 1. Schema of the cell control.

A short description of the local control is provided here, the pressure-based, current driven digital architecture for impedance control is fully explained in. ${ }^{10}$ The equation of the mechanical dynamics of the SDOF piston mode approximation for the loudspeaker is given by:

$$
Z_{m}(s) v(s)=S_{d} p(s)-B l i(s)
$$

where $s$ is the laplace variable, $v(s)$ is the mechanical velocity of the loudspeaker membrane, $p(s)$ is the average sound pressure on the membrane, $S_{d}$ is the equivalent piston area, $B l$ is the force factor of the moving coil, $i(s)$ is the driving current.

The mechanical impedance of the SDOF loudspeaker model in open circuit is expressed as:

$$
Z_{m}(s)=s M+R+\frac{1}{s C}
$$

where $M, R$ and $C$ are respectively the mass, resistance and compliance of the SDOF loudspeaker model.

The transfer function (local control) between the pressure and the current in order to achieve a target impedance $Z_{a t}$ on the loudspeaker membrane is defined as:

$$
H_{l o c}(s)=\frac{i(s)}{p(s)}=\frac{1}{B l}\left(S_{d}-\frac{Z_{m}(s)}{Z_{a t}(s)}\right),
$$

where $Z_{a t}$ is the target impedance:

$$
Z_{a t}(s)=\frac{p(s)}{v(s)}=\mu_{1} \frac{s M}{S_{d}}+R_{a t}+\mu_{2} \frac{1}{s C S_{d}}
$$

with $\mu_{1}$ and $\mu_{2}$ are two coefficients used to respectively tune/reduce the mass ans the stiffness of the loudspeaker in the control, and $R_{a t}$ is a target acoustic resistance to be achieved at the resonance. 


\section{TEST BENCH FACILITY}

The microphones calibration and the identification of the Thiele-Small parameters of each cell have been done in an acoustic duct. The Caïman wind tunnel is an experimental test bench composed by a straight duct with a square $66 \times 66 \mathrm{~mm}^{2}$ section. The cutoff frequency $\left(f_{c}\right)$ of the duct is $2600 \mathrm{~Hz}$. The duct termination reproduces an anechoic condition. Liners until $320 \mathrm{~mm}$ of length along the axial direction can be tested with a maximum speed flow of Mach $0.4(137 \mathrm{~m} / \mathrm{s})$. Acoustic quantities, such as absorption coefficient $(\alpha)$ and insertion loss $(I L)$ are estimated with a 4 microphones technique following the $B \& K$ technical review. ${ }^{11}$ Table 1 summarizes the geometrical parameters. The spacing between pairs of microphones $\left(\Delta_{m i c}\right)$ depends on the frequency range. Experimental tests without flow have been done with a white noise signal between $100 \mathrm{~Hz}$ and $6000 \mathrm{~Hz}$ sampled at $51200 \mathrm{~Hz}$ and an equivalent acoustic level in the duct of $124 \mathrm{~dB}$. The acquisition lasts 30 seconds (30 averages of 1 second). The following list summarizes the experimental equipment (figures 2-3):

- 1 : Computer

- 2 : DAC associated to the electronic cells

- 3 : NI Pxi card (IN/OUT)

- 4 : Audio amplifier

- 5 : Nexus B\&K 2692-C (Charge microphones amplifier)

- 6 : Laboratory power supply $( \pm 5 V, 2 A$ max $)$

- 7 : Caïman cells and frame

- 8 : 1/4" microphones B\&K 4939 and amplifiers B\&K 2670

- 9 : Loud speaker

- 10 : Caïman wind tunnel (straight and square section $66 \times 66 \mathrm{~mm}^{2}$ )

- 11: Anechoic termination

- 12 : Flow until Mach $0.4(137 \mathrm{~m} / \mathrm{s})$

\begin{tabular}{c|c|c|c|c|c}
$x_{1}$ & $x_{2}$ & $x_{3}$ & $x_{4}$ & $d$ & $\Delta_{m i c}$ \\
\hline$x_{2}-\Delta_{m i c}$ & $-0.377 \mathrm{~m}$ & $\begin{array}{c}x_{4}-\Delta_{m i c} \\
\text { Table 1. Geometrical parameters. }\end{array}$ & $0.846 \mathrm{~m}$ & $0.266 \mathrm{~m}$ & $2.2 \mathrm{~cm} \mathrm{or} 10 \mathrm{~cm}$
\end{tabular}

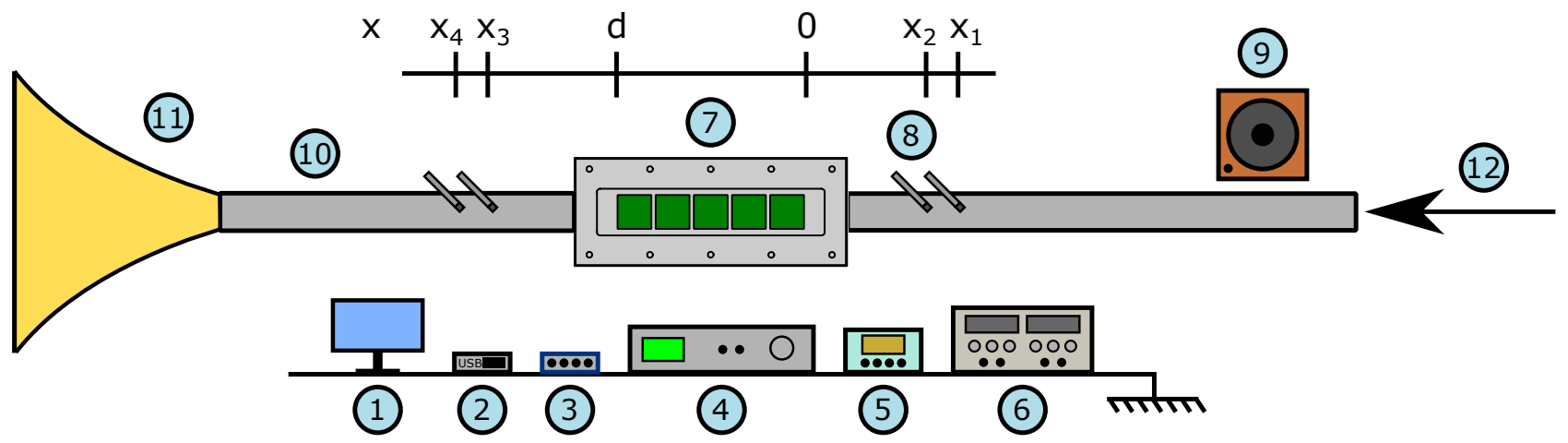

Figure 2. Experimental setup diagram of the Caïman wind tunnel tests. 


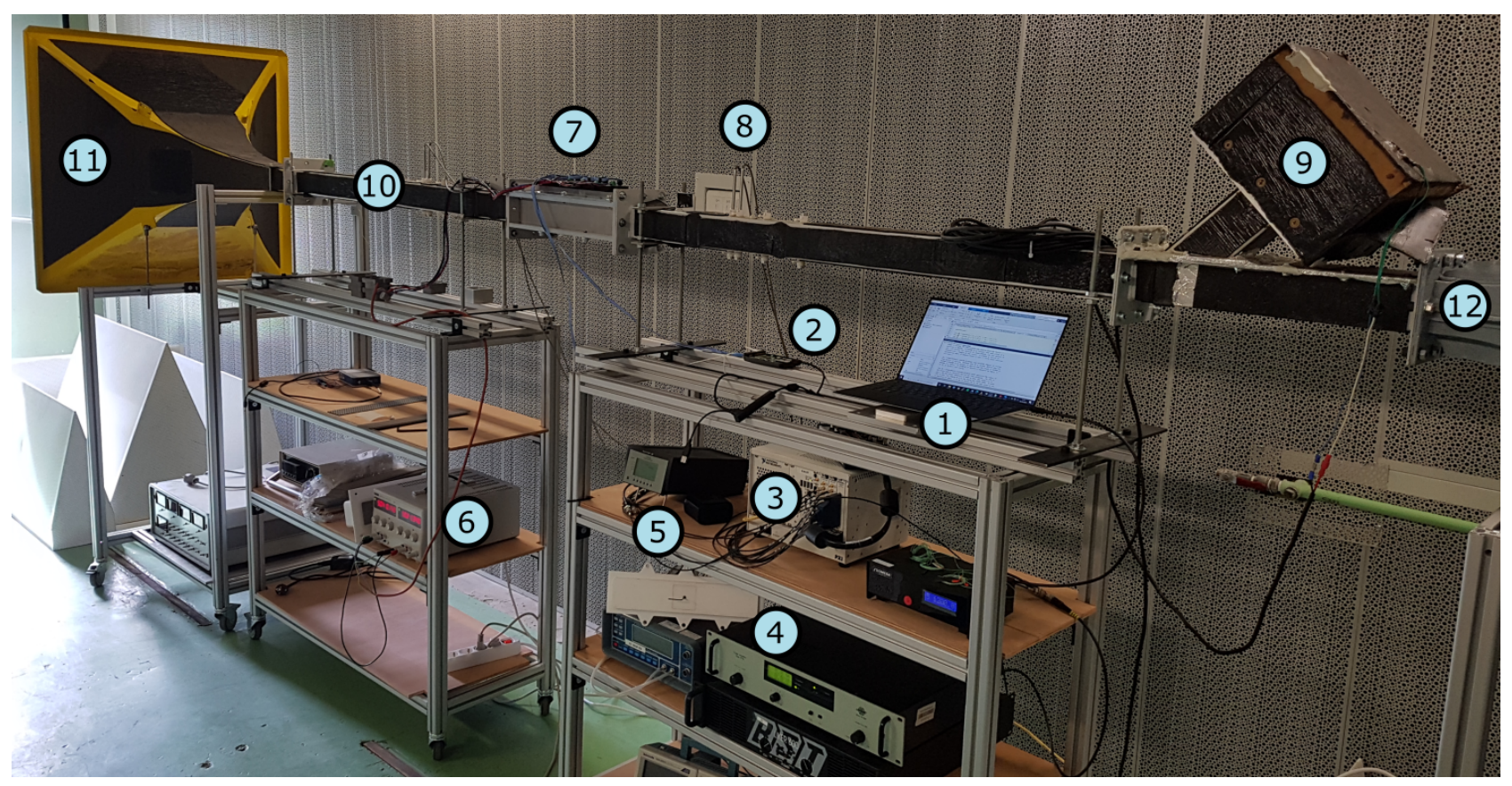

Figure 3. Experimental setup picture of the Caïman wind tunnel tests.

Figure 4a shows the inside view (without wiremesh) of the cells installed in the Caïman wind tunnel. Figure $4 \mathrm{~b}$ shows the outside view with the electronic cards, the wires for the electrical supply and the wires for the communication between the computer and the cells. A rigid panel is installed on the opposite side of the active liner and a wiremesh is added in front of the cells.

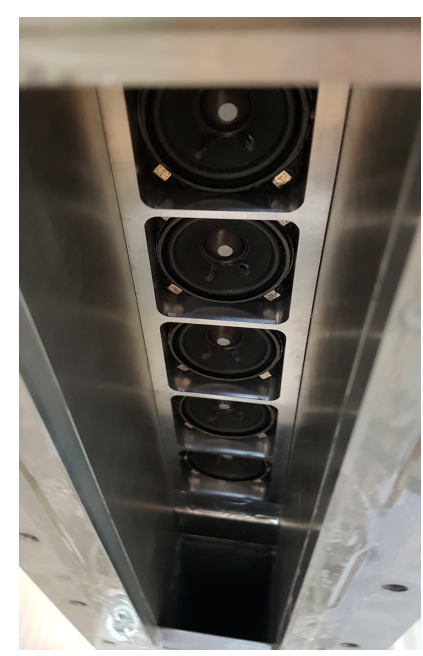

(a)

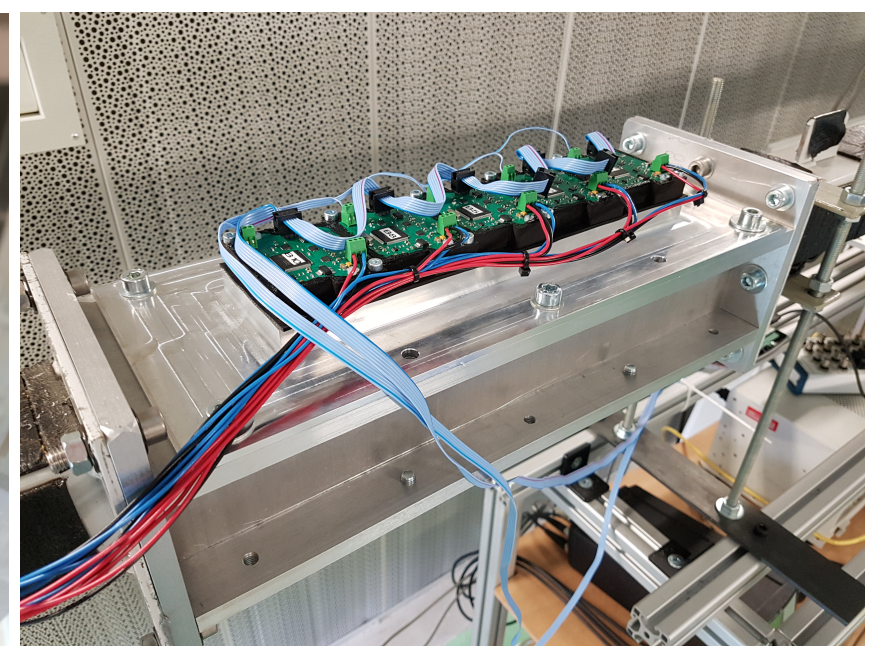

(b)

Figure 4. Caïman cells : a) inside view (without wiremesh), b) outside view. 


\section{EXPERIMENTAL RESULTS}

\subsection{Tests without flow}

This subsection presents the results with a local control law without flow. The efficiency zone (see Table 2) can be tuned by $\mu_{1}$ and $\mu_{2}$ and are centred around the frequency:

$$
f_{e f f}=f_{0} \sqrt{\frac{\mu_{2}}{\mu_{1}}}
$$

\begin{tabular}{|c|c|c|c|c|}
\hline$\mu_{2}$ & 0.2 & 0.4 & 1 & 2 \\
\hline$f_{\text {eff }}[\mathrm{Hz}]$ & 475 & 675 & 1075 & 1510 \\
\hline
\end{tabular}

Table 2. Efficiency frequency zone depending on the parameters of the control law $\left(\mu_{1}=0.4\right)$.

Figures 5 shows the performances of the control when the target impedance takes the following values: $\rho_{0} c_{0}, 2 \rho_{0} c_{0}$ and $0.5 \rho_{0} c_{0}$. The $\mu_{1}$ and $\mu_{2}$ parameters of the local control law are equal to 0.4. The configuration without control is plotted in black. It can be noticed in Figures 5 that the performance increases around the $f_{\text {eff }}$ frequency when the target impedance decreases. The choice of the target impedance is crucial in order to increase the performance compared to the passive solution (without control).

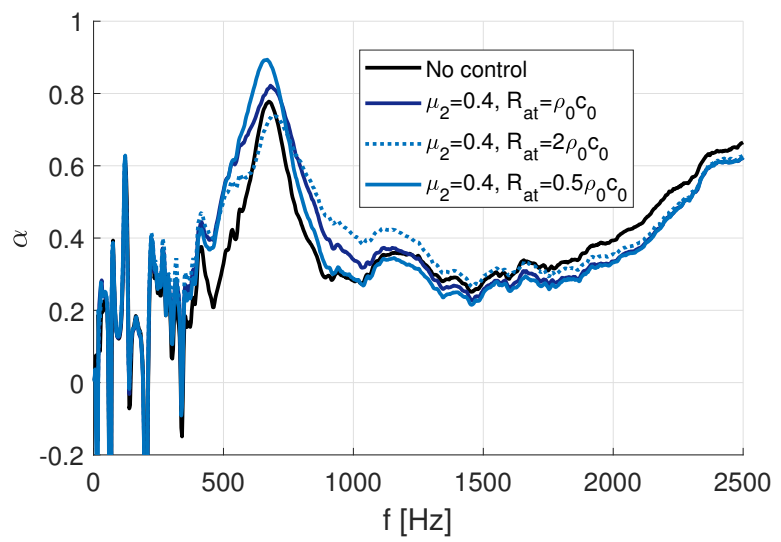

(a)

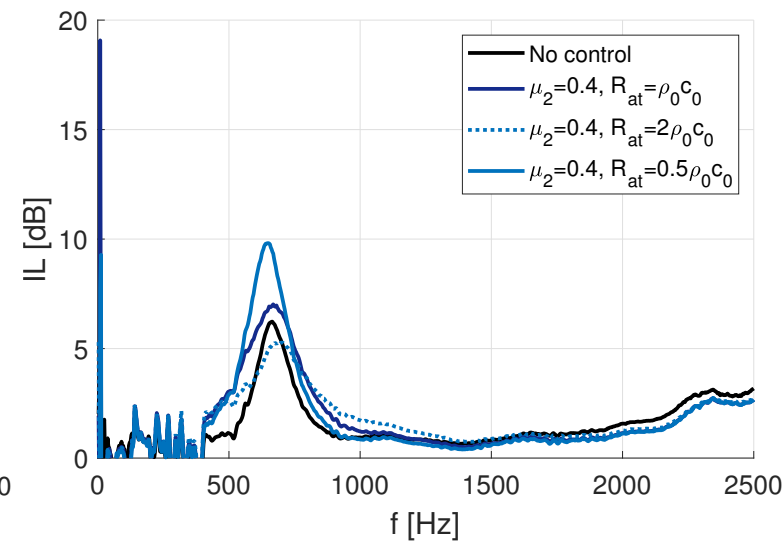

(b)

Figure 5. Variation of the target impedance $\left(R_{a t}=\left[\rho_{0} c_{0}, 2 \rho_{0} c_{0}, 0.5 \rho_{0} c_{0}\right]\right)$. Control law parameters $\left(\mu_{1}=\mu_{2}=0.4\right):$ a) Absorption coefficient $(\alpha)$, b) Insertion loss $(I L)$.

In the following the target impedance is now selected as $R_{a t}=0.5 \rho_{0} c_{0}$. Figures 6 shows the performances of the control when the parameters of the control law are varied. The $\mu_{1}$ parameter of the local law remains equal to 0.4 and $\mu_{2}$ takes the three following values: $0.4,1,2$. In order to reduce the noise at low frequencies $\left(\mu_{2}=0.2\right)$, the spacing between pairs of microphones $\left(\Delta_{m i c}\right)$ has been increased from $2.2 \mathrm{~cm}$ to $10 \mathrm{~cm}$. Consequently, a zero pressure measurement is present at $1700 \mathrm{~Hz}$ corresponding to a half wavelength $(\lambda / 2)$ equal to $10 \mathrm{~cm}$ (the spacing between pairs of microphones). The change in $\mu_{2}$ value is equivalent to change the efficiency frequency from 500 to $1500 \mathrm{~Hz}$.

The results confirm the adaptability and the stability of the whole system with the local control strategy. 


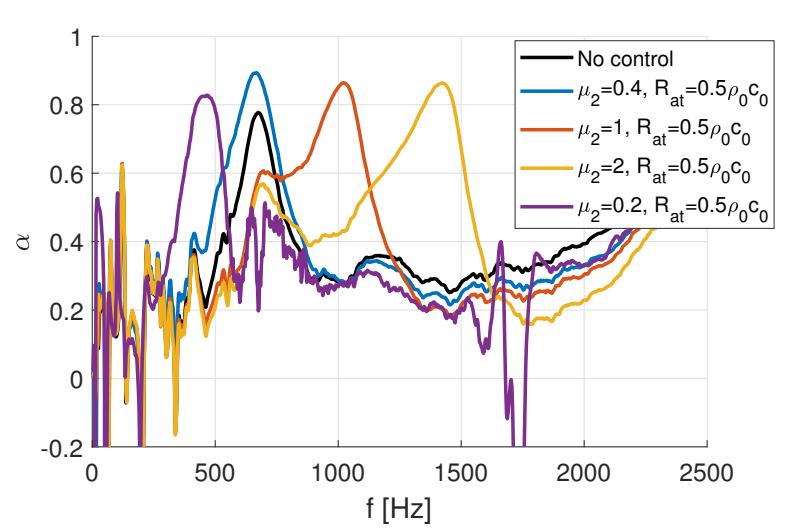

(a)

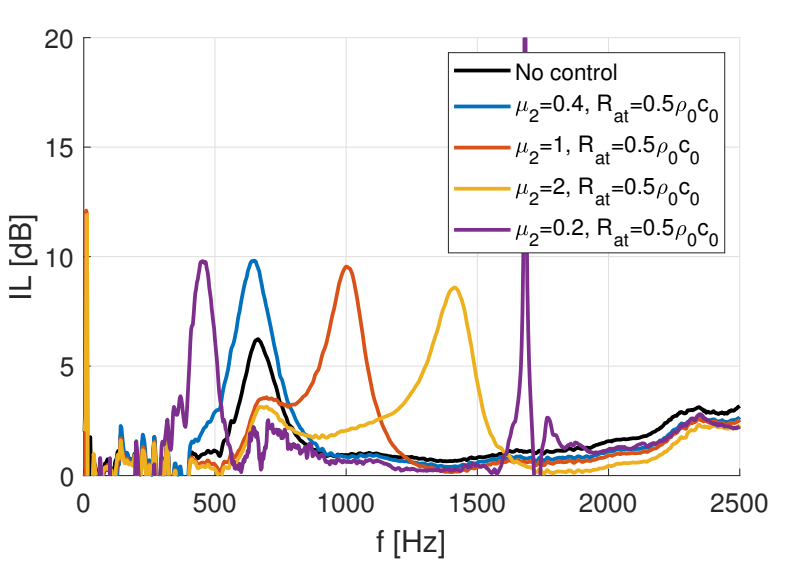

(b)

Figure 6. Variation of the parameters of the control law $\left(\mu_{1}=0.4, \mu_{2}=[0.2,0.4,1,2]\right)$. Target impedance $\left(R_{a t}=\right.$ $\left.0.5 \rho_{0} c_{0}\right)$ : a) Absorption coefficient $(\alpha)$, b) Insertion loss $(I L)$.

\subsection{Tests at different flow speeds}

This subsection presents the results with a local control law with flow. The target impedance has been selected as $R_{a t}=0.5 \rho_{0} c_{0}$.

With flow, the ratio between the signal and the noise was too low with a white noise or a sweep sinus. Therefore, a pure sine has been used to increase the signal over noise ratio and decorrelate the turbulent boundary layer from acoustics. In order to reduce the noise at low frequencies, the spacing between pairs of microphones $\left(\Delta_{\text {mic }}\right)$ has been set at $10 \mathrm{~cm}$.

The flow speed is equal to 20,40,60,80, 100 and $120 \mathrm{~m} / \mathrm{s}$ (Mach 0.06, 0.12, 0.18, 0.24, 0.29 and 0.35). Figures 7 present the results when the flow speed increases. The $\mu_{1}$ and $\mu_{2}$ parameters of the local control law are equal to 0.4 . The reference test without flow is plotted with a deep blue line.

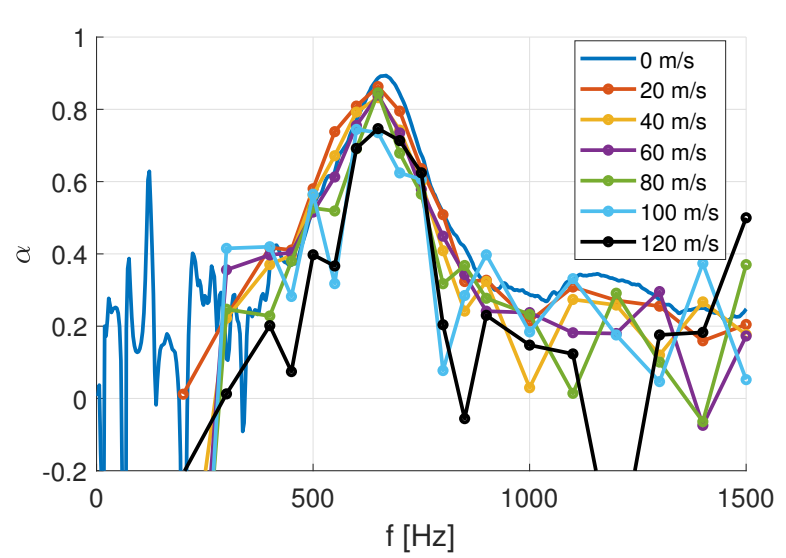

(a)

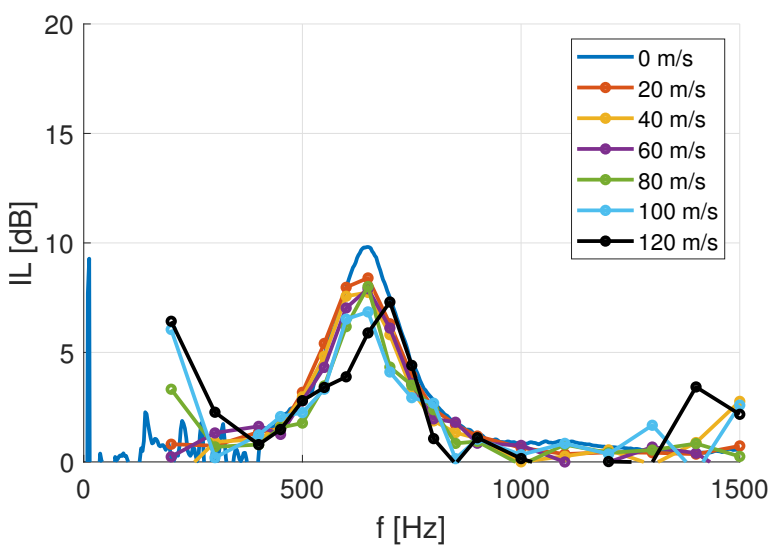

(b)

Figure 7. Variation of flow velocity $[0,20,40,60,80,100,120] \mathrm{m} / \mathrm{s}$, Control law parameters $\left(\mu_{1}=\mu_{2}=0.4\right)$ a) Absorption coefficient $(\alpha)$, b) Insertion loss $(I L)$.

The air flow slightly reduces the efficiency while maintaining the adaptability and the stability.

\section{CONCLUSION}

In this article, experimental results in acoustic flow duct are presented. The active liner is based on an array of electroacoustic absorbers. The control law is based on the pressure-based, current driven digital architecture 
for impedance control with a local control strategy. The adaptability and the stability of the system between 500 and $1500 \mathrm{~Hz}$ with the tested parameters of the local control law have been validated. The air flow slightly reduces the performance.

\section{ACKNOWLEDGMENTS}

The SALUTE project has received funding from the Clean Sky 2 Joint Undertaking under the European Union's Horizon 2020 research and innovation programme under grant agreement No 821093. This publication reflects only the author's view and the JU is not responsible for any use that may be made of the information it contains.

\section{REFERENCES}

[1] H. F. Olson and E. G. May, "Electronic sound absorber," The Journal of the Acoustical Society of America 25(6), pp. 1130-1136, 1953.

[2] D. Guicking and E. Lorenz, "An active sound absorber with porous plate," 1984.

[3] M. Furstoss, D. Thenail, and M.-A. Galland, "Surface impedance control for sound absorption: direct and hybrid passive/active strategies," Journal of sound and vibration 203(2), pp. 219-236, 1997.

[4] H. Lissek, "Shunt loudspeaker technique for use as acoustic liner," in Proceedings of the Internoise 2009: Innovations in Practical Noise Control, pp. 1-8, 2009.

[5] R. Boulandet and H. Lissek, "Optimization of electroacoustic absorbers by means of designed experiments," Applied acoustics 71(9), pp. 830-842, 2010.

[6] H. Lissek, R. Boulandet, and R. Fleury, "Electroacoustic absorbers: bridging the gap between shunt loudspeakers and active sound absorption," The Journal of the Acoustical Society of America 129(5), pp. 29682978, 2011.

[7] R. Boulandet and H. Lissek, "Toward broadband electroacoustic resonators through optimized feedback control strategies," Journal of Sound and Vibration 333(20), pp. 4810-4825, 2014.

[8] R. Boulandet, E. Rivet, and H. Lissek, "Sensorless electroacoustic absorbers through synthesized impedance control for damping low-frequency modes in cavities," Acta Acustica united with Acustica 102(4), pp. 696$704,2016$.

[9] R. Boulandet, H. Lissek, S. Karkar, M. Collet, G. Matten, M. Ouisse, and M. Versaevel, "Duct modes damping through an adjustable electroacoustic liner under grazing incidence," Journal of Sound and Vibration 426, pp. 19-33, 2018.

[10] E. Rivet, S. Karkar, and H. Lissek, "Broadband low-frequency electroacoustic absorbers through hybrid sensor-/shunt-based impedance control," IEEE Transactions on Control Systems Technology 25(1), pp. 63$72,2016$.

[11] J. S. Bolton, T. Yoo, and O. Olivieri, "Measurement of normal incidence transmission loss and other acoustical properties of materials placed in a standing wave tube," Brüel \& Kjær Technical Review (1), pp. 1-44, 2007. 